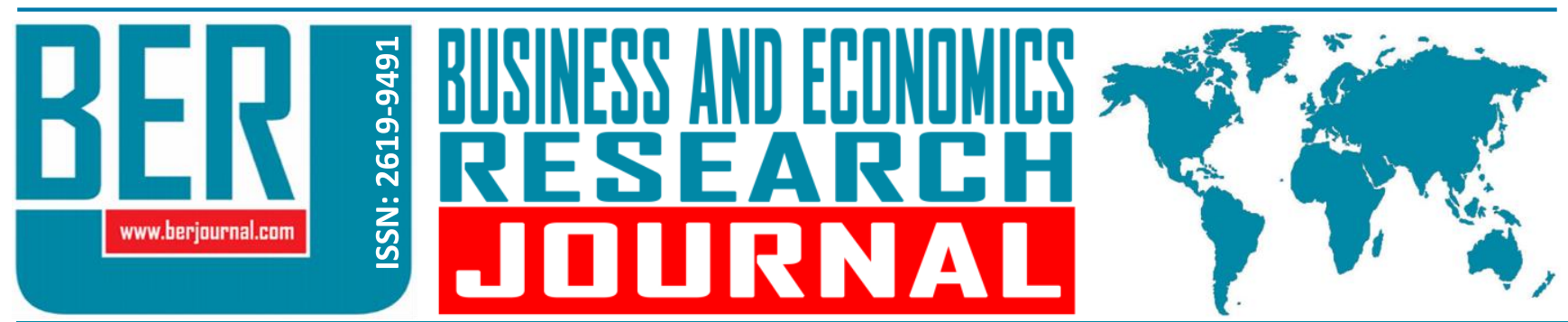

Business and Economics Research Journal Vol. 9, No. 2, 2018, pp. 349-361 doi: 10.20409/berj.2018.109

\title{
Doğal Afet Sigortalarında Karar Alma Sorunları: Kamusal Müdahaleler
}

\section{Tulin Altun ${ }^{\mathrm{a}}$}

Öz: Bu çalışmada doğal afet sigortalarına ilişkin kararlar, davranışsal literatür üzerinden incelenmekte ve kamusal müdahaleler önerilmektedir. Doğal afetlerin gerçekleşme olasılığı düşük ancak sonuçları büyüktür. Doğal afet sigortalarında, risk ve belirsizliğin diğer piyasalara göre daha fazla olması, karar alma sorunlarının daha sık görülmesine yol açmaktadır. Sezgisel düşünme, sistematik önyargılar, öğrenme hataları, sosyal normlar ve sosyal karşılaştırmalar, kamu yardımları ve politik çıkarlar rasyonel olmayan kararlar alınmasına neden olmaktadır. Afet sigortası talep edenler, arz edenler ve düzenleyici bir kurum olarak faaliyet gösteren kamu kesiminin rasyonel davranmaması yetersiz sigorta kapsamına neden olmaktadır. Yetersiz sigorta kapsamı, bireysel ve sosyal refahta kayıplara yol açmakta, devletin örtük mali yükümlülüklerini artırmaktadır. Zorunlu sigorta, çerçeveleme, çok yıllı sigorta sözleşmeleri gibi asimetrik paternalist politik araçlar, karar alma sorunlarını hafifletebilir. Sigortacılık sözleşmelerine ilişkin regülasyonlar ve kamu-özel ortaklıkları piyasa başarısızlıklarını giderebilir.

\section{Decision-Making Problems in Natural Disaster Insurance: Public Intervention}

\begin{abstract}
In this study, decisions about natural disaster insurance is examined through the behavioral literature and public interventions are suggested. Natural disasters are low probability but high consequence events. In natural disaster insurance, the risk and uncertainty are higher than in other markets, leading to more frequent decision-making problems. Intuitive thinking, systematic bias, learning mistakes, social norms and social comparisons, public aids and political interests cause non-rational decisions to be made. Non-rational behavior of insurance consumers, suppliers and public sector, which operates as a regulatory institution causes inadequate insurance coverage. Inadequate insurance coverage leads to loss of individual and social welfare and increases the government's implicit fiscal liabilities. Asymmetric paternalist political instruments, such as mandatory insurance, framing, multi-year insurance contracts can reduce decisionmaking problems. Regulations on insurance contracts and public-private partnerships can resolve market failures.
\end{abstract}

Anahtar Sözcükler: Doğal Afetler, Afet Sigortaları, Davranışsal Teori, Karar Alma Sorunları, Kamu Müdahaleleri

JEL: D81, G22, H40

Geliş: 1 Şubat 2018 Düzeltme: 22 Mart 2018 Kabul: 23 Mart 2018

Keywords: Natural Disasters, Disaster Insurance, Behavioral Theory, DecisionMaking Problems Public Interventions

JEL: D81, G22, H40

Received: 1 February 2018 Revised: 22 March 2018 Accepted: 23 March 2018 


\section{Giriş}

Depremler, şiddetli yağışların neden olduğu taşkınlar gibi doğal afetler oldukça yıkıcı etkilerde bulunmaktadır. Afetin büyüklüğüne göre ortaya çıkabilecek maddi kayıplar ise ekonomik dengeleri alt üst edebilmekte ve etkisi uzun yıllar devam edebilmektedir. Swiss Reassurance Institute SIGMA Raporu'na göre 2016 yılında küresel düzeyde doğal afetler 175 milyar \$'lık ekonomik kayba yol açmıştır. Bu kayıpların yalnızca \% 30'u (54 milyar \$) sigorta şirketlerince karşılanırken 121 milyar \$'lık ekonomik zarar sigorta kapsamı dışında kalmıştır (2017:3-5).

Afet sonrası ekonomik zararların tazmini, hükümetlerin örtük yükümlülükleri kapsamında değerlendirilmekte ve devlet yardımları için güçlü bir toplumsal baskı ortaya çıkmaktadır. Ancak devletin bu yükümlülükleri yerine getirmesinin önünde güçlü mali engeller bulunmaktadır. Devlet, mali yardımlar sağlayabilse bile bu yardımlar toplumsal fayda ve maliyet açısından etkin olmayabilmektedir. Herhangi bir doğal afet gerçekleşmeden önce koruyucu önlemlere yatırım yapılması ve afet sonrası ekonomik kayıpların telafi edilebilmesi için sigorta yaptırılması hem bireysel, hem toplumsal hem de kamu kesimi açısından çok daha etkin bir yöntemdir. Buna rağmen bireyler afet risklerine karşı yeterince koruyucu önlem almamakta ve sigorta yaptırmamaktadırlar. Doğal afetlere karşı koruyucu önlemlerin alınması büyük ölçüde kamu kesiminin regülasyon faaliyetlerine bağlıdır. Merkezi ve yerel yönetimler yerleşim yerlerinin taşınması, imar izinleri, binaları güçlendirme faaliyetleri gibi konularda mevzuatlar oluşturarak, doğal afet risklerine karşı koruyucu önlemlerin çerçevesini oluşturmaktadır. Bunun yanı sıra afet sonrası zararların tazmin edilebilmesi için mülklerin sigorta kapsamına alınmasının sağlanması da önleyici faaliyetler kadar önem arz etmektedir. Kamu kesimi, sigortacılık piyasasına ilişkin düzenlemeler getirerek ve primleri sübvanse ederek de doğal afetlere yönelik politik müdahalede bulunabilmektedirler. Ancak, düzenleyici mevzuatlar ve sigorta kapsamının genişletilmesi için sağlanan sübvansiyonlara rağmen alınan önlemler ve sigorta talebi yetersiz kalmaktadır.

Davranışsal teori, afetlere karşı koruyucu yatırımların yetersizliğini ve sigorta kapsamının bireysel ve sosyal optimumun altında olmasının nedenini davranışsal yanlılıklara göre açıklamaktadır. Bu çalışma kapsamında davranışsal perspektiften, afet sigortalarında gözlemlenen karar alma sorunları tartışılmakta ve bu sorunların çözümü için kamusal müdahaleler önerilmektedir.

Çalışmanın takip eden bölümünde sigortacılık piyasasında karar alma sorunlarına değinilmektedir. Sigorta kararlarında, beklenen fayda modelinden sapmalar, rasyonel olmayan karar alma modelleri ile açıklanmaktadır. Davranışsal nedenlerden ötürü sigorta talebinin bireysel ve sosyal optimumun üzerinde ya da altında olabileceği belirtilmektedir. Çalışmanın üçüncü bölümünde çalışmanın asıl sorunsalı olan afet sigortalarındaki karar alma sorunları analiz edilmektedir. Bu bölümde sigorta talep edenler, arz edenler ve düzenleyici bir kurum olarak kamu kesiminin sahip olduğu davranışsal yanlılıklar sıralanmaktadır. Dördüncü bölümde sigortacılık piyasasına devletin müdahale gerekçeleri, piyasa başarısızlıkları ve davranışsal nedenlere göre ele alınmaktadır. Beşinci bölümde afet risklerinde eksik sigortalanmanın önüne geçilmesi için kullanılabilecek politik araçlardan bahsedilmektedir. Son bölüm sonuç ve değerlendirmelerdir.

\section{Sigortacılık Piyasasında Karar Alma Sorunları}

Sigortacılık piyasasının ekonomik analizinde, beklenen fayda modeline göre normatif analizler yapılır. Bu modele göre riskten kaçınan bireyler, risklere karşı sigorta primi ödemeye istekli olurlar. Bekledikleri zarara eşdeğer olan aktüeryel açıdan makul bir fiyatla sigorta teminatı satın alırlar. Sigorta şirketleri ise portföylerini çeşitlendirerek risklerini yaymak isterler (Ehrlich ve Becker, 1972; Johnson, Hershey, Meszaros ve Kunreuther, 1993). Risk ve belirsizlik altında karar alan rasyonel bireyler Bayesci kuralları kullanarak (her aşamada elde ettikleri bilgileri güncelleyerek), beklenen yararını en üst düzeye çıkaracak şekilde hareket ederler (Harsanyi, 1978). Böylelikle sigorta, kaynakların marjinal faydasının düşük olduğu yerlerden, yüksek olduğu yerlere aktarılması işlevini görür (Cutler ve Zeckhauser, 2004). Bununla birlikte, asimetrik bilginin yol açtığı ahlaki tehlike ve ters seçim problemleri (Akerlof, 1978; Rothschild ve Stiglitz, 1976) ortaya çıkabilmekte ve piyasa etkinliği bozulabilmektedir. Ters seçim problemi için kamu müdahaleleri (riski yaymak için zorunlu sigorta) ve ahlaki tehlike problemi için sigorta şirketinin riskin tamamını üstlenmeyeceği kısmi kapsamlı 
sigortalar ya da prim indirimleri kullanılması yoluyla, sorunların üstesinden gelinebilmektedir (Johnson vd., 1993).

Ancak sigortacılık piyasasını davranışsal açıdan analiz eden oldukça geniş bir literatür, sigorta piyasasında alınan kararların beklenen fayda teorisi ile uyuşmadığını iddia etmektedir. Birçok çalışmada davranışsal yanlılıkların, piyasa başarısızlıkları ile etkileşime girdiği ve sigorta piyasalarında optimal dengeye ulaşılamadığı belirtilmektedir. Maliyete kıyasla beklenen faydanın düşük olmasına rağmen aşırı sigorta yaptırılabilmekte ya da maliyetlerinin beklenen faydaya göre küçük olmasına rağmen eksik sigorta yaptırılabilmektedir. Richter, Schiller ve Schlesinger (2014), riskler ve belirsizlikler nedeniyle, sigortacılık piyasasının davranışsal perspektiften incelenmesi için oldukça uygun bir alan olduğunu belirtmektedirler. Yazarlara göre davranışsal perspektif klasik teorinin bazı varsayımlarına ikame teoriler getirerek ya da onları tamamlayarak, teori ile gözlemler arasındaki tutarsızlıklardan bazılarını açıklayabilme gücüne sahiptir.

Davranışsal teorinin geleneksel iktisat teorisine en önemli eleştirisi rasyonel birey varsayımıdır. Rasyonel birey varsayımının temelinde, her bireyin kendi refahının en iyi karar vericisi olduğu, yargılarının istikrarlı, tutarlı tercihler tarafından yönetildiği, tercihlerin seçimlere yön verdiği ve fayda sağlamak için seçim yapıldığı önermeleri bulunmaktadır. (Bernheim, 2016). Ancak davranışsal teori, ihmal, irade eksikliği, kayıptan kaçınma, cari döneme daha fazla ağırlık verme, sezgisel düşünme (Simon, 1955; Kahneman ve Tversky, 1979; Thaler ve Benartzi, 2004; Kahneman, 2011) gibi davranışsal özelliklerden ötürü sınırlı rasyonalite varsayımı kabul etmektedir. Bu tür davranışsal özellikler, neo-klasik teorinin öngördüğünün aksine, bireylerin fayda maksimizasyonu yapacak şekilde rasyonel karar alamamalarına neden olmaktadır. Risk ve belirsizliğin önemli olduğu sigortacılık piyasasında ise davranışsal özellikler, rasyonel olmayan kararlar üzerinde daha belirleyici olmaktadır.

Sigorta piyasasındaki karar alma sorunları sadece sigorta talep eden tüketicilere mahsus bir özellik değildir. Sigorta şirketleri ve kamu kesimi de davranışsal yanlılıklar gösterebilmektedir. Örneğin Kunreuther (2015), ABD'de 2001 yılındaki 11 Eylül saldırılarından sonra birçok sigorta şirketinin uzman tahminlerinin üzerinde, terör riskini aşırı algıladıklarını ve en kötü senaryoya odaklanarak bu risklerini sigorta kapsamından çıkardıklarını söylemektedir. Kamu kesimi ise risklerin gerçekleşme olasılığını düşük tahmin ederek, yeterince düzenleyici kural getirmeyebilmektedirler.

Sigorta şirketleri ve kamu kesimi yöneticilerinin davranışsal yanlılıklar göstermesi genel olarak eksik sigortaya neden olurken, tüketicilerin davranışsal yanlılıklar göstermesi hem eksik hem de aşırı sigorta yaptırmalarına neden olabilmektedir. Bireyler olumsuz bir deneyimin büyüklüğünü, gerçekte yaşadığı kayıptan çok daha fazla tahmin etme eğilimi içindedirler. Ayrıca bu kayıpların kalıcı olacağını düşünebilmektedirler. Kayıptan kaçınma duygusu bireylerin aşırı sigorta almasına neden olabilmektedir. Gelirin marjinal faydasını önemli ölçüde etkilemeyecek (parasal açıdan değersiz) ancak refahı önemli ölçüde düşürecek (manevi açıdan değerli) riskler söz konusu olduğunda da kaygı düzeyini azaltmak için aşırı sigorta yaptırılabilmektedir (Cutler ve Zeckhauser, 2004). Thaler (1980), bu konuyu pişmanlık kavramına başvurarak ele almaktadır. Tüketiciler daha sonra pişmanlığın getireceği psikolojik maliyetleri üstlenmemek için bu tür sigortaları yaptırmak istemektedirler.

Aşırı sigorta yaptırma davranışı, kaynak tahsisatında etkinsizliklere yol açsa da genel olarak kamu müdahalesini gerektirdiği konusunda bir görüş birliği olduğu söylenemez. Eksik sigorta yaptırma davranışı ise, toplumsal refahı olumsuz etkilediği ve örtük kamusal yükümlülükleri artırdığı gerekçesi ile kamusal müdahalenin kabul edildiği bir alandır. Eksik sigorta yaptırma davranışı çoğunlukla, düşük olasılıklı yüksek sonuçlu riskler söz konusu olduğunda (afetler, terör felaketleri vb.) çok daha fazla ortaya çıkmaktadır.

\section{Afet Sigortalarında Karar Alma Sorunları}

Bu bölümde sezgisel düşünme, sistematik önyargılar, öğrenme hataları, sosyal normlar ve sosyal karşılaştırmalar gibi davranışsal sorunların yanı sıra, yardım ikilemi ve politikacı ikilemi başlıkları altında piyasa başarısızıkları ve kamu kesiminin düzenlemeleri ile etkileşim sonucu ortaya çıkan karar alma sorunlarına yer verilmektedir. 


\subsection{Sezgisel Düşünme}

Sezgisel düşünme (intuitive thinking), az ya da hiç çaba harcanmadan kendiliğinden gerçekleşen hızlı düşünme biçimidir. Genellikle kişisel deneyimlerle kazanılan göz kararı kuralları bu düşünceye rehberlik etmektedir. Bilinçli düşünme (deliberative thinking) ise zahmetli zihinsel etkinlikleri gerektirmektedir. Seçimler genellikle bu iki düşünme biçiminin birleştirilmesi ile yapılmaktadır. Bu şekilde alınan kararlar rasyonel sonuçlar doğurabilmektedir (Kahneman, 2011). Kuntreuther ve Pauly (2014), deneyimlerin fazla olduğu alanlarda riske ilişkin algıların nispeten daha rasyonel olduğunu belirtmektedirler. Ancak gerçekleşme olasılı̆̆ı düşük olan, sonuçları büyük olabilecek risklerde, deneyimlerin yetersizliği sezgisel düşünme biçiminin daha çok kullanılmasına neden olmaktadır.

Sezgisel düşünen bireyler, fayda maliyet analizini optimal bir şekilde yapamamaktadırlar. Örneğin bir birey evini afete karşı güçlendirmek için bir yatırım yaparken, bunun maliyetini evi için yapacağı herhangi bir yatırımın (örneğin musluk tamiri) maliyeti ile karşılaştırabilmektedir. Afet gerçekleşmeden önce bu yatırımın faydasını göremeyeceği için önleyici faaliyetler için yapacağı harcamaları boşuna yapılmış harcamalar olarak değerlendirebilmektedir (Kunreuther, Meyer ve Michel-Kerjan (2013). Bu düşünce biçimi sigorta kararlarında da geçerli olabilmektedir. Bir felaket gerçekleşmeden önce hem sigorta şirketleri hem de risk altındaki bireyler sezgisel düşünerek risk olasılıklarını hafife almaktadırlar. Felaket gerçekleştiğinde ise sigorta şirketleri ve sigorta talep edenler felaketin yol açtığı kayıplara aşırı odaklanmakta ve gelecek risk olasıııklarını aşırı değerlendirme eğilimine girmektedirler (Kunreuther, 2016). Politika yapıcılar ise bir afet gerçekleşmeden önce, afet sigortalarında gerçek riski yansıtan primleri düşürmeye yönelik düzenlemeler yapmaktadırlar. Yakın bir tarihte bir afet yaşanmaz ise bu strateji politikacılara olumlu getiriler sağlamaktadır. Uzun vadede ise aşırı sübvanse edilen prim ödemeleri etkinsiz sonuçlar doğurabilmektedir (Kunreuther ve Pauly, 2014). Bu üç tarafın sezgisel düşünmesi, sigorta faaliyetinin en önemli hedeflerini gerçekleştirememesine neden olmaktadır. Sigorta, risk altındaki bölgelerde ikamet edenlere karşılaşacakları riskler konusunda bilgi sağlamamaktadır. Ayrıca riskli kişileri sigorta yaptırmaya teşvik etmemektedir (Kunreuther, 2015).

\subsection{Sistematik Önyargılar}

Bireyler belirsizlik durumunda hem risklerin boyutu ve olasılıkları konusunda, hem de sigortanın fayda ve maliyetine ilişkin değerlendirmelerinde sistematik ön yargılar (systematic bias) ile hareket etmektedirler (Johnson vd., 1993). Cari döneme, gelecek dönemden daha fazla ağırlık verme (present bias) (Kahneman ve Tversky, 1979; Laibson, 1997), belirsizlik durumunda seçim yapmayı erteleme (inertia) (Tversky ve Shafir, 1992), risk olasılıklarını aşırı iyimser şekilde değerlendirme (Kahneman, 2003), statüko yanlılı̆ı (status quo bias) (Kahneman ve Tversky, 1979) gibi sistematik önyargılar sergilediğinde optimal sigorta talebine ulaşılamamaktadır.

Risk altındaki bireyler, hiperbolik indirgemeden dolayı, gelecek dönemdeki faydaları, cari dönemdeki maliyetlerini aşsa bile sigorta primi maliyetlerine katlanmak istemeyebilmektedirler. Sağlık sigortası alanında Aboluck ve Gruber'in (2011) çalışması, bireylerin yakın dönemde ödedikleri primlere, uzun dönemli faydalardan daha fazla ağırlık verdiğine ilişkin kanıtlar sunmaktadır.

Belirsizlik durumunda seçim yapmak, çok fazla değişkenin dikkate alındığı karmaşık zihinsel süreçleri gerektirmektedir. Bu zorlayıcı zihinsel sürecin psikolojik maliyetine katlanmak istemeyen bireyler, seçim yapmamayı tercih edebilmektedirler. Ayrıca Ritov ve Baron (2000), bireylerin bir eylemden kaynaklanan sonuçlardan pişman olma eğiliminin, eylemsizlikten kaynaklanan pişman olma eğiliminden daha fazla olduğunu belirtmektedirler. Çok çeşitli afet sigortası poliçeleri içinde seçim yapmak durumunda kalan bireyler, seçim yapmayı sürekli erteleyebilmektedir.

Herhangi bir afet gerçekleşmeden önce, bu afetlerin gerçekleşme olasılığı hafife alınmaktadır. Bireylerin risklere ilişkin iyimser tahminleri, onların yetersiz önlem almalarına ve sigorta yaptırmamalarına neden olabilmektedir. Bununla birlikte riski hafife alan bireyler, herhangi bir olumsuz deneyim yaşadıktan sonra önlem almamanın pişmanlığını aşırı şekilde hissedebilmekte, gördüğg̈ zararı çok fazla tahmin edebilmektedir (Gilbert, Pinel, Wilson, Blumberg ve Wheatley, 2002). Böyle bir pişmanlık hissi, sigortaya olan talebi optimal düzeyin de üzerinde artırabilir. Ancak, yaşanan deneyimin büyüklüğüne göre, yaşanan 
pişmanlık hissi zamanla etkisini kaybetmektedir. Doğal afet önemli ölçüde zarar vermediyse ya da uzun zaman önce gerçekleşti ise afetin psikolojik etkileri zamanla hafiflemekte ve hatırlanabilirliği azalmaktadır. Bu durumda ise görmezden gelme eğilimi tekrar kendini göstermektedir (Kunreuther, 2016; 2015). Dolayısıyla bir felaket sonrasında sigorta talebi aşırı şekilde artsa bile, talepteki bu artışlar kısa süreli olmaktadır. MichelKerjan, Lemoyne de Forges ve Kunreuther (2012), ABD'de 2001-2009 yılları arasında ulusal sel sigortası programı kapsamındaki sigorta poliçeleri taleplerini inceledikleri çalışmalarında, poliçelerin elde tutulma süresinin ortalama 2-4 yıl arasında olduğunu tespit etmişlerdir. Bunun nedenini rasyonel ekonomik sebeplerin yanı sıra davranışsal yanlılıklara bağlamışlardır. Felaketlerin etkisinin zamanla hafızadan silinmesi, sigortaların tekrar iptal edilmesine neden olmaktadır. Atreya, Ferreira ve Michel-Kerjan (2015) de benzer sonuçlara ulaşmışlardır. ABD'de Ulusal sel Sigortası programı verilerinden (1978-2010) yararlanarak sel sigortası satın alma davranışını analiz etmişlerdir. Davranışsal ekonomi literatürüyle uyumlu şekilde, son zamanlarda meydana gelen taşkın olaylarının sigorta alımını artırdığı, ancak bu etkinin 3 yıl sonra kaybolduğunu tespit etmişlerdir.

Bireyler herhangi bir eylemde bulunmanın sağlayacağı kazanç ve kayıpları değerlendirirken, statükolarını referans noktası olarak almakta ve mevcut durumlarından uzaklaşmak istememektedirler. Statüko yanlılığının temel nedeni kayıplara kazançlardan daha fazla ağırlık verilmesidir. Bu nedenle sigorta primlerinin maliyetine, faydasından daha fazla ağırlık verilmektedir.

\subsection{Sosyal Normlar}

Davranışsal iktisat alanında sosyal normların bireysel kararlar üzerinde etkili olabileceğini gösteren birçok çalışma bulunmaktadır. Sosyal normlar betimleyici (descriptive norms) ve buyruksal (injunctive norms) olmak üzere iki ayrı kategoride değerlendirilebilir. Betimleyici norm neyin tipik ve normal olduğunu gösterirken, buyruksal norm ahlaki açıdan onaylanan kuralları göstermektedir (Cialdini, Reno ve Kallgren, 1990). Bireyler kalabalığın aklına ya da değer yargılarına güvenerek, kararlarını başkalarının davranışlarına göre alabilmektedirler. Başkalarının afetlere karşı sigorta yaptırmadığını gören bireyler, kalabalığın aklına güvenerek sigorta yaptırmama kararı alabilmektedirler. Bunun yanı sıra afet sigortası yaptırmanın toplumsal açıdan kabul gören erdemli bir davranış olduğuna dair herhangi bir buyruksal normun yokluğunda, bireyleri sigorta yaptırmaya iten herhangi bir sosyal norm bulunmayacaktır.

\subsection{Sosyal Karşılaştırmalar}

Bireyler sosyal karşılaştırma (social comparision) yaparak kendi refahlarını çevresindeki insanların refahına göre değerlendirebilmektedirler. Bir başka deyişle başkalarının refahını referans noktası olarak kullanılabilmektedirler (Tverky ve Kahneman, 1992). Dolayısıyla bireylerin, kendi refahlarını maksimize etmeye yönelik kararları, toplumsal bağlamdan etkilenmektedir. Friedl, Lima de Miranda ve Schmidt (2014), sosyal bağlamın, risk altındaki bireylerin sigorta kararları üzerinde de önemli etkileri olabileceğini belirtmektedirler. Sosyal bağlamın risk alma ve sigorta yaptırma davranışını nasıl etkilediğini test etmek için 149 katılımcısı olan bir deney yapmışlardır. Elde ettikleri bulgulara göre sadece kişiyi etkileyecek riskler söz konusu olduğunda (örneğin cep telefonu sigortası), sigorta maliyetlerinin yüksekliğine rağmen bireyler sigorta yaptırmayı tercih etmektedirler. Ancak doğal afetler gibi riskler söz konusu olduğunda, sigorta primleri önemli ölçüde kamu tarafından sübvanse edilse bile sigorta talep düzeyi düşük olmaktadır. Yazarlar bunun sosyal karşılaştırmalardan kaynaklandığı sonucuna ulaşmışlardır. Doğal afetler sadece kişiyi etkilememektedir. Bu riskler kişinin çevresindekilerin riskleri ile yüksek oranda ilişkilidir. Herhangi bir doğal afet olduğunda sadece kişinin kendisi değil, çevresi de bundan büyük ölçüde zarar görmektedir. Sosyal karşılaştırma yapan bireyler, kendi refah düzeylerindeki kayıpları, başkalarının kayıpları ile karşılaştırmakta ve bireysel bir felakete kıyasla öznel iyi oluşlarını daha yüksek düzeyde değerlendirebilmektedirler. Doğal afet gibi toplumu etkileyen riskler söz konusu olduğunda, sosyal karşılaştırmalar bu risklere karşı daha az sigorta yaptırılmasına neden olmaktadır. 


\section{5. Öğrenme Hataları}

Insanların afet risklerine maruz kalma olasılıkları düşüktür. Dolayısıyla bu konuda ders çıkarabilecek kadar deneyime sahip değillerdir. Yetersiz deneyim öğrenme hatalarından (learning failures) biridir. Diğer bir neden ise afetlere karşı kamu yardımları konusunda öğrenilen bilgilerdir. Bir afet sonrasında devlet afetzedelere yardım yapıyorsa ve kişiler bunu medyadan ya da kendi çevresinden öğreniyorsa, afetlere karşı önlem almanın gereksiz olduğunu düşünebilmektedirler (Kunreuther vd., 2013). Bu nedenle sigorta yaptırmayabilmektedirler.

\subsection{Ahlaki Tehlike: Yardım İkilemi}

Sigortacılık piyasasına ilişkin geleneksel ekonomik analizlerde, asimetrik bilgiden kaynaklanan ahlaki tehlike (moral hazard) (Akerlof, 1978; Rothschild ve Stiglitz, 1976) problemlerine sıklıkla değinilir. Afetler kişinin eylemleri ile ilgili değil, dış kaynaklı olduğu ve kayıplar sadece parasal olmadığı halde afet sigortalarında da ahlaki tehlike sorunları ortaya çıkabilmektedir. Sigortalı bireyler zararlarının tazmin edileceğini bildiği için, riskleri azaltmaya yönelik yatırımlar yapmayabilmektedirler. Ancak Hudson, Botzen, Czajkowski ve Kreibich (2017), afet sigortalarında, davranışsal özelliklerden dolayı ahlaki tehlikenin ortaya çıkmayabileceğini belirtmektedirler. Almanya ve $A B D^{\prime}$ de üzerine yaptıkları ekonometrik analizlerinin sonuçlarına göre, risk azaltma eylemleri ile sigorta birbirini tamamlayıcı işlev görmektedir. Botzen, Kunreuther ve Michel-Kerjan (2017) çalışmalarında da afet sigortalarında ahlaki tehlikenin her zaman ortaya çıkmadığı sonucuna ulaşılmıştır. Kişilerin risk algıları, geçmişteki hasar deneyimleri gibi davranışsal özellikler, sigorta kararları ve risk azaltma yatırımları üzerinde benzer etkilerde bulunmaktadır. Ancak yakın gelecekte bir afet riski söz konusu olduğunda sigorta, risk azaltma yatırımlarının ikamesi olabilmektedir. Yazarlar, afet sigortalarında, ahlaki tehlikenin spesifik bir türünün ortaya çıktığını tespit etmişlerdir. Federal afet yardımları ile hasarlar telafi edildiğinde, sigortasız hanelerin gönüllü sigorta alma olasılıkları düşük bulunmuştur.

Afet sonrasında merkezi hükümetlerin ya da diğer ulusal ya da uluslararası kuruluşların yardım yapacağının umulması, zararlarının tazmin edileceğini düşünen bireylerin sigorta yaptırmamasına neden olabilmektedir. Buchanan (1975) ve Kunreuther vd. (2013) bu durumu yardım ikilemi (samaritan dilemma) olarak adlandırırken, Raschky ve Weck-Hannemann (2007), yardım tehlikesi (charity hazard) olarak adlandırmaktadırlar. Yardım tehlikesi, yerel yönetimler için de geçerli olabilmektedir. Merkezi hükümetlerin afet hasarlarını karşılayacağını düşünen yerel yönetimler, afet öncesi koruma önlemlerini benimsemeyebilmektedirler.

\subsection{Politikacı İkilemi}

Siyasetçilerin uzun vadeli toplumsal çıkarlar açısından afet koruma önlemlerini benimsemeleri, afet sonrası hasarların tazmin edilmesi için sigorta kapsamını genişletecek düzenlemeler yapması gerekmektedir. Ancak politikacıların karşılaştıkları ikilem (politician's dilemma) onların etkin kararlar alamamasına neden olmaktadır. Politika yapıcılar, sosyal, teknik, politik, idari, hukuki, ekonomik birçok faktörü hesaba katarak karar alırlar. Bu faktörler aşağıda sıralanan sorunlardan ötürü etkin bir afet yönetiminin oluşturulmasında engel oluşturabilmektedir (Petak, 1985):

- Politika yapıcılar diğer mevcut sorunları daha acil ve önemli olarak algılayabilirler.

- Afet önlemleri alınmasını destekleyen seçmenler ve çıkar gruplarının siyasi gücü zayıf olabilir.

- Siyasi ve ekonomik maliyetler arasında bir ödünleşmenin olması yasa koyucuların harekete geçmesini önleyebilir.

- Sosyal değer yargıları ile gerçekler her zaman uyuşmayabilir.

Bir afet gerçekleştiği takdirde, afet zararlarının karşılanması için önemli kamu harcamaları yapmak gerekmektedir. Bu durum hükümetleri zor durumda bırakabilmekte, bütçe açıklarına kamu borç artışlarına neden olabilmektedir. Dolayısıyla siyasetçilerin uzun vadeli ve kısa vadeli çıkarları açısından alacakları kararlar 
farklılaşabilmektedir. Siyasetçiler kısa vadede, popülist politikaları tercih edebilmekte ve kamu kaynaklarını seçmenlerden daha fazla destek alacakları alanlara kaydırabilmektedirler.

Politikacılar ve bürokratlar, tüketicileri zorlayıcı müdahalelerde bulunmak yerine hiçbir düzenleme yapmamayı ya da zararları telafi edecek kamusal tazminat uygulamalarını tercih edebilmektedir. Pauly, Kunreuther ve Vaugel (1984) göre bunun temel nedeni politikacıların yeniden seçilme kaygısıdır. Bireyler genellikle doğal afet risklerinin gerçekleşme olasılı̆ını ve afet sonrası karşılaşacakları maliyetleri rasyonel bir şekilde değerlendiremezler. Bu durumda yeniden seçilmek ya da görevde kalmak isteyen politikacı ve bürokratların, zorlayıcı düzenlemeler ile rasyonel olmayan seçmenin desteğini almaları zordur. Seçmenlerin rasyonel olmayan şekilde kendi çıkarlarını maksimize etmek istemesi ve politikacıların buna uygun politik cevaplar vermesi, toplumsal refah düzeyini en çoklaştıracak bir sigorta politikasının geliştirilememesine neden olmaktadır. Büyük hasar veren bir afet meydana gelinceye kadar, sigorta piyasasına ilişkin kamusal düzenlemeler geciktirilmektedir.

Bir doğal afet meydana geldiğinde ise politikacılar, sigorta kapsamı ve primlerine ilişkin politik düzenlemeler yapılması konusunda seçmenlerin desteğini alabilmektedirler. Afetlere karşı sigorta kapsamının genişletilmesi için ulusal sigorta programları oluşturulabilmekte ya da özel afet sigortaları sübvanse edilebilmektedir. Ancak politikacılar çıkarları doğrultusunda, sigorta primlerinin riski yansıtmayacak şekilde düşük tutulmasına yönelik düzenlemeler de yapmaktadırlar. Aşırı sübvanse edilmiş bir sigortacılık sektörü, riskleri yeterince kapsamayacaktır. Bir felaket olduğunda, sigorta programları hasarları karşılayacak kapasiteye sahip olmayacaklardır. Bu durumda zararların tazmini için hazine kaynaklarına müracaat etmek gerekmektedir. Yeterli mali alan olmadığında, hükümetler ciddi borç krizleri ve bütçe açıkları ile karşılaşacaklardır. Yeni vergiler ve harcama kısıntıları gündeme gelecektir. Vergi artışları politikacılara seçimsel bir maliyet yüklemektedir. Bununla birlikte yıkıcı etkisi büyük olan bir felaketin finansmanı için alınan vergilere karşı toplumsal direnç düşüktür. Ayrıca bireyler, riski yansıtan sigorta primlerinin maliyetini, afet yardımları için alınan vergilerin maliyetinden fazla algılayabilirler.

Sonuç olarak politikacıların seçim desteği alabilme kaygısı ve seçmenlerin rasyonel kararlar alamaması nedeniyle, afet sigortalarına yönelik kamusal müdahaleler de optimal sigorta dengesini sağlayamayabilir.

\section{Sigortacılık Piyasasına Kamusal Müdahale Gerekçeleri}

Dışsallıklar, eksik piyasalar gibi piyasa başarısızlıkları söz konusu olduğunda ya da gelir dağılımı konuları gündeme geldiğinde devletin piyasalara müdahale etmesi gerektiği yaygın bir şekilde kabul edilmektedir. Davranışsal teori sadece piyasa başarısızlıkların değil, davranışsal yanlııkların da kamu müdahalesinin bir gerekçesi olabileceğini söylemektedir. Üstelik kamusal müdahaleler sadece sosyal refah artışı için değil, bireysel refah artışının sağlanması için de önerilmektedir. Bununla birlikte geleneksel iktisat teorisinde, devletin bireysel davranışları değiştirmek için yapacağı müdahaleler, paternalistik müdahaleler olarak adlandırımakta ve tüketici egemenliğini sarstığı gerekçesiyle bu tür politikalara kuşkuyla yaklaşılmaktadır. Bu görüşe göre paternalistik müdahaleler, bireysel özgürlüklere saygı duymamakta ve bireylerin fayda maksimizasyonu yapmalarını engelleyerek piyasa başarısızıklarına yol açmaktadır. Bununla birlikte davranışsal teori, hem bireysel özgürlüklere zarar vermeyecek hem de davranışsal karar alma sorunlarının üstesinden gelebilecek şekilde alternatif paternalist politikalar uygulanabileceğini iddia etmektedir. Sunstein ve Thaler (2003), bu tür alternatif politikaları, liberter paternalizm olarak adlandırırken, Camerer, Issacharoff, Loewenstein, O'Donoghue ve Rabin (2003), bu politikaları asimetrik paternalist politikalar olarak kavramsallaştırmaktadırlar.

Camerer vd. (2003), asimetrik paternalist politikalar ile rasyonel bireylere hiç maliyet yüklemeksizin ya da küçük maliyetler getirerek, rasyonel olmayan bireylerin çok maliyetli hatalar yapmasının önüne geçebileceğini iddia etmektedirler. Bu yaklaşıma göre devlet, kendileri için uygun karar almayan bireylere yönelik değil, durumlara ilişkin düzenleyici kurallar getirebilir. Bu tür asimetrik paternalist politikaları, hazır seçenekler (default rules), bilgi sağlanması ve bilginin çerçevelenmesi (provision or re-framing of information), bekleme süresi (cooling off period) ve seçme süresine ilişkin sınırlandırmalar (limiting consumer 
choices) olmak üzere dört temel alanda örneklendirirler. Sigortacılık piyasası açısından ilk iki politika önerisi oldukça işlevsel olabilmektedir.

Sigortacılık sektörü açısından piyasa başarısızlıkları ve davranışsal yanlılıkların her ikisi de kamusal müdahaleler için gerekçe oluşturabilmektedir. Sigortacılık alanında en temel piyasa başarısızlığı asimetrik bilginin varlığıdır. Asimetrik bilginin yol açtığı ters seçim problemini giderecek kamusal müdahaleler, sosyal refah artışını sağlayacağı gerekçesi nedeniyle kabul görmektedir. Rothschild ve Stiglitz (1976), zorunlu sigorta uygulamalarının Pareto iyileştirme sağlayacağını ortaya koymuşlardır. Bu modele göre sigortacılık piyasasında, tek bir denge oluşmayacak, düşük riskli iktisadi ajanlar ile yüksek riskli ajanlar için sigortanın kapsamı ve fiyatı ayrılacaktır. Düşük riskli bireyler daha düşük prim ödemeli kısmi sigorta poliçesini seçerken, yüksek riskli kişiler, daha yüksek prim ödemeli tam kapsamlı sigorta poliçesini tercih edeceklerdir. Zorunlu sigorta uygulamaları, düşük riskli bireylerin dağııımı belli bir eşiğin üzerinde olduğu müddetçe her iki grubu da daha iyi duruma getirecektir. Her risk grubu da aynı sigorta havuzunda toplanıldığı için düşük riskli bireyler, yüksek riskli bireylerin sigorta maliyetinin bir kısmını üstlenecektir. Bu durum yüksek riskli kişileri daha iyi hale getirecektir. Zorunlu sigorta, riskin yayılımı nedeniyle, düşük riskli kişilerin de prim ödemelerinin daha düşük olmasını sağlayacaktır.

Karar alma sorunlarının üstesinden gelmek ve bireysel refah artışını sağlamak için davranışsal teori de, zorunlu sigorta önerilerinde bulunmaktadır. Bununla birlikte Sandroni ve Squintani (2007), davranışsal gerekçeler ile asimetrik bilgi gerekçesinin, zorunlu sigorta müdahalesi için birbirini tamamlayıcı gerekçeler olmadığını söylemektedir. Davranışsal perspektiften, bireyler yüksek risklere sahip olsalar bile kendine aşırı güvendiği (iyimser olduğu) için, sigorta yaptırmamayı tercih ettiğinde, zorunlu sigorta bu kişilerin refahına katkı sağlayacaktır. Ancak bu kişiler yüksek risklerine rağmen kısmi kapsamlı ve düşük prim ödemeli sigorta poliçelerini tercih edeceklerdir. Aşırı iyimser bireylerin ekonomide önemli bir ağırlığı olduğunda, düşük riskli bireyler yüksek riskli bireyleri daha fazla sübvanse etmek zorunda kalacaktır. Sigorta şirketleri, kendine aşırı güvenen yüksek riskli kişiler ile düşük riskli kişiler arasında bir ayrım yapamadığında zorunlu sigorta düşük riskli bireyler için refah artışını sağlamayacak, Pareto iyileştirmeler söz konusu olmayacaktır.

Doğal afetler gibi bazı sigorta piyasalarında birbirini tamamlayıcı şekilde olmasa bile hem piyasa başarısızlıkları hem de davranışsal başarısızıkların önüne geçebilecek kamusal müdahaleler yapılması imkanı bulunmaktadır. Afet risklerinde asimetrik bilginin yol açacağı ters seçim problemleri nispeten önemsiz kalmaktadır. Afet riski taşıyan tehlikeli bölgeler konusunda birçok bilgi kaynağının bulunması ya da binaların risklere karşı dayanıklılığının uzmanlar tarafından tespit edilebiliyor olması, düşük riskli kişiler ile yüksek riskli kişilerin ayırt edilebilmesini sağlamaktadır.

\section{Afet Risklerinin Eksik Sigortalanmasını Önleyecek Politik Araçlar}

Emeklilik, sağlık, trafik, mülkiyet sigortaları gibi davranışsal sigorta analizlerinde önerilen kamusal müdahaleler genel olarak bireysel refah artışına katkısı bağlamında ele alınmaktadır. Afet sigortaları alanında yapılacak kamusal müdahaleler ise, bireysel refahın yanı sıra, toplumsal refah ve kamu kesiminin mali istikrarı açısından da değerlendirme yapılmasını gerektirmektedir.

\subsection{Zorunlu Sigorta}

Afetlere karşı zorunlu sigorta, hem ters seçim problemi hem de davranışsal yanlılıkların üstesinden gelmek için kullanılabilecek yöntemlerden biridir. Zorunlu sigorta, riskin yayılımını sağlayarak, piyasanın kapsamını genişletmektedir. Bireyler, sezgisel düşünme, sistematik önyargılara sahip olma ya da öğrenme hataları nedeniyle karar alma sorunları yaşadıklarında, zorunlu sigorta, refah artışını sağlayacak normatif bir seçim olarak değerlendirilebilir.

Kunreuther ve Pauly (2014), doğal afetlerden kaynaklanan kayıpların, vergi mükelleflerinin parasıyla karşılanan kamusal yardımlarla telafi edilmesinin yerine, zorunlu sigorta aracılığıyla risk altındaki kişilerin mali açıdan kendilerini korumalarının sağlanmasının sosyal refah açısından da önemli bir konu olduğunu vurgulamaktadırlar. 
Ancak zorunlu sigorta mevzuatının oluşturulmasına yönelik bazı politik engeller bulunmaktadır. Vatandaşlar, sigorta prim maliyetlerini üstlenmek yerine, kamu yardımlarına güvenebilmektedirler. Politikacılar, yeniden seçilme kaygısı ile afet sigortalarını zorunlu hale getirmek yerine, afet hasarlarını kamu bütçesinden karşılamayı tercih edebilmektedirler. Böylelikle hem kısa vadede seçmenlere bir maliyet yüklemeyerek onların desteğini alabilmekte, hem de seçimlerden önce afet yardımlarını popülist amaçlar için kullanabilmekte ya da kendilerini destekleyen seçim çevrelerine afet yardımları aracılığıyla daha fazla kaynak aktarabilmektedirler. Bürokratlar, afet yardımlarının temin edilmesinde ve ihtiyaç bölgelerine ulaştırılmasında önemli roller üstenmektedir. Zorunlu sigorta yetki alanını küçülteceği için, bürokratların da bu konudaki motivasyonları düşük olabilmektedir (Raschky ve Weck-Hannemann, 2007).

Örneğin, Almanya'da 2003-2004 yılları arasında fırtına, sel deprem gibi tüm afetleri kapsayan tek bir sigorta poliçesi ile karşılanabilecek, zorunlu sigorta mevzuatının oluşturulması için politik bir gündem oluşmuştur. Merkezi hükümetin ve federal hükümetlerin maliye bakanları görüşmelere başlamış ancak görüşmeler sonucu bir uzlaşıya varılamamıştır. Schwarze ve Wagner (2007), bunun en önemli sebeplerini politik nedenlere bağlamaktadırlar. Merkezi ve federal hükümetler arasındaki dağılımsal çatışmalar, yeniden seçilme kaygıları, özel sigortayı teminat altına almak için devlet güvencelerinin rolünü tanımlama başarısızığı, sistemin kurulamamasına neden olmuştur.

Zorunlu sigorta uygulamasındaki bir başka engel ise karşılanabilirlik sorunudur. Yüksek riskli ancak düşük gelirli kişiler sigorta primlerinin maliyetini karşılayamayabilirler. Bu engeli aşmanın bir yolu, yüksek gelirli bireylerin yüksek prim ödemeleri aracılığıyla düşük gelirli bireyleri sübvanse etmesidir. Ancak bu durumda primler risklerle doğru orantılı olmayacak, düşük riskli kişiler yüksek riskli kişileri finanse etmek durumunda kalacaklardır. Primlerin riskleri yansıtmaması, piyasada etkinsizliklere yol açacaktır. Düşük gelirli kişiler açısından karşılanabilirlik problemini çözmenin etkin yolu ise genel kamu harcamaları yoluyla yapılan sübvansiyonlardır (Kunreuther, 2016).

\section{2. Çerçeveleme}

Bireyler düşük olasılıklı riskleri görmezden geliyor ise, risk olasılıklarının daha somut bir bağlamda sunulması (çerçeveleme-framing) etkili bir yöntem olabilmektedir. Risklerin daha şeffaf ve somut hale getirilmesi algılamayı kolaylaştırmaktadır. Örneğin riskin yıllık gerçekleşme olasılı̆̆ına ilişkin bilginin verilmesi yerine 25-50 yıllık gerçekleşme olasılıklarına ilişkin bilgiler verilebilir. Bu şekilde yapılan bir çerçeveleme, yeni sigorta talebi yaratmasa bile, mevcut sigortalıların poliçelerini iptal etmemesini sağlayabilmektedir (Kunreuther, 2015; 2016). Sigorta poliçelerinin hazır seçenekler olarak sunulması da, karar almanın bilişsel yükünü hafifleteceği için etkili bir yöntem olabilir.

Bireyler, risk olasılıkları ve sonuçları ile ilgisi olmayan (fayda ve maliyetlere ilişkin bilgi içermeyen) bazı faktörlerden etkilendiğinde de çerçeveleme yaklaşımı kullanılabilir. Devlet, firmaların sözleşme çerçevelerine ek bilgiler koyması için bir düzenleme getirebilir. Bu tür düzenlemeler de rasyonel olmayan insanları hiç etkilemezken, rasyonel olmayan insanların daha iyi karar almalarını sağlayabilmektedir. Bireyler belirsiz ve riskli durumlarda çeşitli sigorta poliçeleri arasında seçim yapmaktan kaçındığında (statüko yanlılığı olduğunda) hazır seçeneklerin tüketiciye atanması da sağlanabilir (Camerer vd., 2003).

\subsection{Sigortacılık Sözleşmelerine iliş̧kin Regülasyonlar}

Risk olasılıkları ya da afet sigortanın fayda ve maliyetlerine ilişkin bilgilere ulaşımasını sağlayacak mekanizmaların geliştirilmesi, bireysel refahı artırma potansiyeline sahiptir. Lee (2017), sigorta şirketlerinin, tüketicilerden çok daha fazla bilgiye sahip olduğunu, ancak bilgiyi açıklama konusunda motivasyonlarının düşük olduğunu belirtmektedir. Kamu kesimi, yaptığı mevzuat düzenlemeleri ile risk olasılıkları ve kayıpların büyüklüğü hakkında sigortacıların bilgi sağlamasını zorunlu tutabilir. Bilgi sağlayacak alternatif kuruluşların kurulması teşvik edilebilir. Lee'nin önerileri her ne kadar küçük risklere karşı aşırı sigorta yaptırma eğiliminin önüne geçilmesi için yapılmış olsa da, risk ve kayıplara ilişkin bilgi mekanizmalarının geliştirilmesi, afet risklerine karşı eksik sigorta yaptırma eğiliminin önüne geçilmesini de sağlayabilir. Bilgi mekanizmaları, riskler ve kayıplar konusunda sigorta şirketlerinin bilgilendirilmesi için de kullanılabilir. 
Kamu kesiminin geliştirdiği standartlara göre binaların afetlere karşı dayanıklılığını gösteren bina kodları belirlenebilir ve standartları karşılayanlara onay belgeleri verilebilir. Bu tür bir kamusal düzenleme genel olarak risk azaltıı yatıımların yapılmasını teşvik edici olmakla birlikte sigorta risk primlerinin bina kodlarına göre belirlenmesi sigorta piyasalarının etkinliğini artırıcı işlev görebilir (Kunreuther, 2015; 2016).

Kamu kesimi, sigorta maliyetlerinin karşılanabilirliği sorununu çözmek için primleri düşürücü düzenlemeler de yapabilmektedir. Bu durumda primler gerçek riskleri yansıtmamakta ve piyasa mekanizmasının işleyişi bozulabilmektedir. Bunun önüne geçilmesi için, kamu kesiminin primlere ilişkin düzenlemeler konusunda dikkatli davranması gerekmektedir.

Afet sonrası kamu kesiminin sunacağı mali yardımlar, sigortalı olma koşuluna bağlanabilir.

\subsection{Mülkün Sigortalanması ve Çok Yıllı Sigorta Poliçeleri}

Afetler sonrası, bireyler yaşadıkları pişmanlık neticesinde, önceki riskler değişmemiş olsa bile sigorta yaptırma kararı alabilmektedirler. Ancak yaşadıkları pişmanlığın etkisi zamanla kaybolmakta ve mevcut sigorta poliçelerini iptal ettirebilmektedirler. Bu tür bir davranışsal yanlılığın önüne geçilmesi için çok yıllı sigorta sözleşmeleri kullanılabilir. 3-5 hatta 10 yıllık sigorta sözleşmeleri düzenlenebilir (Michel- Kerjan vd., 2012). Çok yıllı sigorta poliçeleri yıllık poliçelere kıyasla hem sigorta yaptıranlar hem de sigortacılar açısından birçok avantaja sahiptir. Sigortalananlar açısından çok yıllı poliçeler prim istikrarı sunmaktadır ve herhangi bir afet olduğunda primlerde önemli bir artış yaşanmamaktadır. Ayrıca bireylerin bütçe planlamalarında belirliliğin olmasını sağlamaktadır. Sigortacılar açısından ise çok yıllı poliçeler sigortalarını iptal eden kişi sayısını sınırlandırarak, sigortacıların riski yaymasına izin vermekte ve pazarlama maliyetlerini azaltıcı etkide bulunmaktadır (Kunreuther ve Michel-Kerjan, 2015). Sigortalar mülk sahiplerinden ziyade bina ile bağlantılı şekilde yapılabilir. Böylelikle, mülklerin el değiştirmesi durumunda sigorta poliçelerinin iptal edilmesinin önüne geçilebilir..

\subsection{Afet Sigortalarında Kamu Özel Ortaklıkları}

Michel Kerjan (2006), yerleşim yerlerinde risk azaltma önlemlerinin alınmasında ve zararların tazmin edilmesinde, kamu ve özel sektörün rol ve sorumluluklarının net bir şekilde tanımlanmadığını belirtmektedir. Kamu sektörünün ulusal sigortalar aracılığıyla riskleri sigortalaması ve primleri aşırı şekilde sübvanse etmesi, kamu sigorta programlarının mali kriz ile karşı karşıya kalmalarına neden olmaktadır. Özel sigortalar ise büyük bir felaket sonrası iflas etme tehlikesiyle karşı karşıyadır. Bu nedenle piyasa teşviklerini köreltmeksizin özel sektör ile kamu sektörü işbirliği ve koordinasyonuna dayalı düzenlemeler yapılmasını önermektedir. Özel sigortacılık temelinde risk esasına dayalı primleri ve düşük gelirli kişiler için genel kamu finansmanından karşılanan sübvansiyonların kullanılması gerektiğini belirtir.

Kamu kesimi afet risklerine karşı, özel sigorta şirketlerini de kapsayacak şekilde ulusal sigortaların kurulması için girişimlerde bulunabilir. Ulusal sigortalar aracılığıyla, özel sektörün karşılayamayacağı kayıplara karşı sigorta sağlanmış olur. Sigortacılar kapasite yetersizliği nedeniyle piyasadan çekildiğinde, devlet reasürans olanakları önemli bir rol oynayabilir. Reasürans ve risk transfer araçları sigorta şirketlerinin karşılama kapasitelerini etkiler (Kunreuther, 2015).

\section{Sonuç}

Doğal afet sigortaları, afetler sonucu ortaya çıkan ekonomik kayıpların etkin bir şekilde tazmin edilmesinde önemli bir rol üstlenmektedir. Ancak afet sigortaları bireysel ve sosyal optimumun altında yaptırılmaktadır. Davranışsal teori, eksik sigortalanma davranışının sadece piyasa başarısızıkları ile açıklanamayacağını belirtir. Davranışsal teoriye göre risk ve belirsizliklerin önemli olduğu sigortacılık piyasasında bireyler beklenen fayda modelinin öngörülerine göre hareket etmemektedir. Davranışsal yanlılıklar, bireylerin fayda maksimizasyonu yapamamalarına neden olmakta, eksik ya da aşırı sigortalanma davranışı ortaya çıkmaktadır. Afet riskleri söz konusu olduğunda ise, davranışsal nedenler çoğu zaman eksik sigorta yaptırma kararına neden olmaktadır. Risklerin ortaya çıkma olasılığının düşük, sonuçlarının ise büyük olduğu afet risklerinde, sigorta şirketleri ve kamu kesimi de rasyonel olmayan kararlar alabilmektedirler. Bu 
tür risklerle karşı karşıya olan tüm taraflar, sezgisel düşündüğü, sistematik önyargılara ve öğrenme hatalarına sahip olduğu için ya da bireyler sosyal normlara ve sosyal bağlama göre karar verdikleri için sigorta piyasasında optimal dengeye ulaşılamamaktadır. Ayrıca bir piyasa başarısızlığı olan asimetrik bilgi, davranışsal yanlılıklarla etkileşime girebilmekte ve ahlaki tehlikenin özel bir türü olan yardım ikilemine neden olabilmektedir. Rasyonel olmayan seçmen tercihleri varsayımında, politika yapıcıların kendi çıkarlarını kollamaları, kısa vadeli oportünistik kararlara yol açabilmektedir.

Geleneksel ekonomi teorisi, sosyal refahın artırılabilmesi için sigortacılık sektöründe ortaya çıkan piyasa başarısızlıklarına devlet müdahalesini öngörür. Davranışsal teori ise sadece sosyal refah artışı için değil, bireysel refah artışı için de paternalistik politik müdahalelerde bulunulabileceğini belirtir. Davranışsal teoriye göre, rasyonel karar alan bireyleri hemen hemen hiç etkilemeyecek ancak rasyonel olmayan bireylerin kararlarında değişiklikleri sağlayacak asimetrik paternalist politikalar, liberal anlayış ile ters düşmemektedir.

Afet risklerinin eksik sigortalanmasını önleyecek asimetrik paternalist politik araçlar, zorunlu sigorta, çerçeveleme, çok yıllı sigorta sözleşmeleri olarak sıralanabilir. Sigortacılık sözleşmelerine ilişkin regülasyonlar ve afet sigortalarında kamu-özel ortaklıkları ise genel olarak piyasa başarısızlıklarının üstesinden gelinmesi için hali hazırda kullanılabilen politik araçlardır. Ancak, politika yapıcıların da davranışsal yanlılıklara sahip olabileceği ve kendi çıkarlarını maksimize etme motivasyonları olduğu göz önünde bulundurulduğunda, etkin bir politika tasarımı yapmak bir hayli güçleşmektedir. Bu çalışmada, afet sigortalarında görülen karar alma sorunları ve bu sorunları çözebilecek politik araçlar, davranışsal literatür üzerinden örneklendirilmiştir. Hangi politik araçların seçileceği ve ne ölçüde kullanılacağına ilişkin stratejiler, en nihayetinde ülkelerin sosyoekonomik, politik yapısına ve çeşitli afet türlerinin görülme sıklığına göre değişecektir.

\section{Kaynaklar}

Abaluck, J., \& Gruber, J. (2011). Choice inconsistencies among the elderly: Evidence from plan choice in the medicare part D program. American Economic Review,101(4), 1180-1210.

Akerlof, G. A. (1978). The market for lemons: Quality uncertainty and the market mechanism. Uncertainty in Economics, $84(3), 235-251$.

Atreya, A., Ferreira, S., \& Michel-Kerjan, E. (2015). What drives households to buy flood insurance? New evidence from Georgia. Ecological Economics, 117, 153-161.

Bernheim, B. D. (2016). The good, the bad, and the ugly: a unified approach to behavioral welfare economics. Journal of Benefit-Cost Analysis, 7(1), 12-68.

Botzen, W. W. J., Kunreuther, H., \& Michel-Kerjan, E. (2017). Protecting against disaster risks: Why insurance and prevention may be complements. The Wharton Risk Management and Decision Processes Center Working Paper, No.5.

Buchanan, J. M. (1975). The Samaritan's dilemma. in E. S. (ed., Phelps), Altruism, Morality and Economic Theory', Russell Sage Foundation, 71-85.

Camerer, C., Issacharoff, S., Loewenstein, G., O’Donoghue, T., \& Rabin, M. (2003). Regulation for conservatives: Behavioral economics and the case for asymmetric paternalism. University of Pennsylvania Law Review, 151(3), 1211-1254.

Cialdini, R. B., Reno, R. R., \& Kallgren, C. A. (1990). A focus theory of normative conduct: Recycling the concept of norms to reduce littering in public places. Journal of Personality and Social Psychology, 58(6), 1015-1026.

Cutler, D. M., \& Zeckhauser, R. (2004). Extending the theory to meet the practice of insurance. Brookings-Wharton Papers on Financial Services, No.1.

Ehrlich, I., \& Becker, G. S. (1972). Market insurance, self-insurance, and self-protection. Journal of Political Economy, 80(4), 623-648.

Friedl, A., Lima de Miranda, K., \& Schmidt, U. (2014). Insurance demand and social comparision: An experimental analysis. Journal of Risk and Uncertainty, 48, 97-109.

Gilbert, D. T., Pinel, E. C., Wilson, T. D., Blumberg, S. J., \& Wheatley, T. P. (2002). Durability bias in affective forecasting. In Heuristics and biases: The psychology of intuitive judgment (Ed. Gilovich, T., Griffin, D., \& Kahneman, D.), Cambridge University Press, Cambridge, 292-312. 
Harsanyi, J. C. (1978). Bayesian decision theory and utilitarian ethics. The American Economic Review, 68(2), $223-228$.

Hudson, P., Botzen, W. W. J., Czajkowski, J., \& Kreibich, H. (2017). Moral hazard in natural disaster insurance markets: Empirical evidence from Germany and the United States. Land Economics, 93(2), 179-208.

Johnson, E. J., Hershey, J., Meszaros, J., \& Kunreuther, H. (1993). Framing, probability distortions, and insurance decisions. Journal of Risk and Uncertainty, 7(1), Special Issue: Making Decisions About Liability and Insurance, 35-51.

Kahneman, D. (2003). Psychology for behavioral economics. The American Economic Review, 93(5), 1449-1475.

Kahneman, D. (2011). Thinking, fast and slow. Farrar, Straus and Giroux. New York.

Kahneman, D., \& Tversky, A. (1979). Prospect theory: An analysis of decision under risk. Econometrica, 47 (2), $263-292$.

Kunreuther, H. (2015). The role of insurance in reducing losses from extrem events: The need for public-private partnerships. The Genava Papers on Risk and Insurance Issues and Practice, 4, 741-762.

Kunreuther, H. (2016). Reducing losses from catastrophes: Role of insurance and other policy tools. Environment: Science and Policy for Sustainable Development, 58(1), 30-37.

Kunreuther, H., \& Michel-Kerjan, E. (2015). Demand for fixed price multi year contracts: Experimental evidence from insurance decisions. The Wharton Risk Management and Decision Processes Center Working Paper, No.4.

Kunreuther, H., \& Pauly, M. (2014). Behavioral economics and insurance: Principles and solutions. The Wharton Risk Management and Decision Processes Center Working Paper, No.1.

Kunreuther, H., Meyer, R., \& Michel-Kerjan, E. (2013). Overcoming decision biases to reduce losses from natural catastrophes. In: The Behavioral Foundations of Public Policy (Ed. Shafir, Eldar), Princeton University Press, Princeton, 398-411.

Laibson, D. (1997). Golden eggs and hyperbolic discounting. Quarterly Journal of Economics, 112(2), 443-478.

Lee, K. (2017). Consumer perception, information provision, and regulation of insurance market. Journal of Regulatory Economics, 51(1), 1-17.

Michel-Kerjan, E. (2006). Disaster and public policy: Can market lessons help address government failures?. In: Proceedings of the 99th National Tax Association Conferance, November 16-18, Boston, MA, 179-187.

Michel-Kerjan, E., Lemoyne de Forges, S., \& Kunreuther, H. (2012). Policy tenure under the U.S. national flood insurance program (NFIP). Risk Analysis, 32(4), 644-658.

Pauly, M., Kunreuther, H., \& Vaugel, J. (1984). Public protection against mispercived risks: Insight from positive political economy. Public Choice, 43(1), 45-64.

Petak, W. J. (1985). Emergency management: A challenge for public administration. Public Administration Review, 45 (Special Issue: Emergency Management: A Challange for Public Administration), 3-7.

Raschky, P. A., \& Weck-Hannemann, H. (2007). Charity hazard: A real hazard to natural disaster insurance?. Environmental Hazard, 7(4), 321-329.

Richter, A., Schiller, J., \& Schlesinger, H. (2014). Behavioral insurance: Theory and experiments. Journal of Risk and Uncertainty, 48, 85-96.

Ritov, I., \& Baron J. (1990). Reluctance to vaccinate: Omission bias and ambiguity. Journal of Behavioral Decision Making, 3(4), 263-277.

Rothschild, M.I., \& Stiglitz, J. (1976). Equilibrium in competitive insurance markets: An essay on the economics of imperfect information. The Quarterly Journal of Economics, 90(4), 629-649.

Sandroni, A., \& Squintani, F. (2007). Overconfidence, insurance, and paternalism. The American Economic Review, 97(5), 1994-2004.

Schwarze, R., \& Wagner, G. G. (2007). The political economy of natural disaster insurance: Lessons from the failure of a proposed compulsory insurance scheme in Germany. Environmental Policy and Governance, 17(6), 403-415.

Simon, H. A. (1955). A behavioral model of rational choice. The Quarterly Journal of Economics, 69 (1), 99-118.

Sunstein, C, R., \& Thaler, R. (2003). Libertarian paternalism is not an oxymoron. The University of Chicago Law Review, 70(4), 1159-1202.

Swiss Reinsurance Institute. (2016). Natural catastrophes and man-made disasters in 2016: A year of widespread damages. Swiss Re Sigma Reports, No.2, Zurich. http://media.swissre.com/documents/sigma2_2017_en.pdf.

Thaler, R. (1980). Toward a positive theory of consumer choice. Journal of Economic Behavior and Organization, 1(1), 39-60. 
Thaler, R., \& Benartzi, S. (2004). Save more tomorrow: Using behavioral economics to increase employee saving. Journal of Political Economy, 112, 164-187.

Tversky, A. \& Shafir, E. (1992). Choice under conflict: The dynamics of deferred decision. Psychological Science, 3(6), 358-361.

Tversky, A., \& Kahneman, D. (1992). Advances in prospect theory: Cumulative representation of uncertainty. Journal of Risk and Uncertainty, 5, 297-323. 
This Page Intentionally Left Blank 